\title{
KETAHANAN GALUR KEDELAI (Glycine max L.) TERHADAP SERANGAN ULAT GRAYAK (Spodoptera litura F.) BERDASARKAN KARAKTERISTIK TRIKOMA
}

\author{
Eko Budi Minarno, Ika Khoiriyah
}

\author{
Jurusan Biologi, Fakultas Sains dan Teknologi \\ UIN Maulana Malik Ibrahim Malang
}

\begin{abstract}
Abstrak
Ulat grayak (Spodoptera litura F.) adalah hama kedelai (Glycine max L.). Pengendalian hama dilakukan dengan penggunaan galur tahan hama melalui seleksi karakteristik morfologi daun (kerapatan trikoma). Penelitian ini bertujuan untuk mengetahui intensitas kerusakan daun oleh serangan hama, dan korelasi antara kerapatan trikoma daun kedelai dengan ketahanan galur terhadap serangan ulat grayak. Penelitian ini dibagi menjadi 2 tahap yaitu penelitian deskriptif dan eksperimental menggunakan Rancangan Acak Lengkap (RAL), 2 kali ulangan. Apabila terdapat perbedaan nyata maka dilanjutkan dengan uji Beda Nyata Terkecil (BNT) 5\%. Perlakuan yang digunakan adalah 45 galur kedelai dan S. litura instar II sejumlah 450 ekor. Data hasil penelitian meliputi nilai intensitas kerusakan daun, ketahanan galur oleh serangan ulat grayak dan kerapatan trikoma. Hasil penelitian menunjukkan bahwa berdasarkan nilai intensitas kerusakan daun, ketahanan 45 galur kedelai (Glycine max L.) dapat dikelompokkan menjadi 4 galur kategori sangat tahan (ST), 4 galur tahan (T), 9 galur agak tahan (AT), 24 galur rentan $(R)$, dan 3 galur sangat rentan (SR). Perbedaan galur kedelai (Glycine max L.) berpengaruh nyata terhadap ketahanan dari serangan ulat grayak (S. litura). Berdasarkan kerapatan trikoma diketahui menunjukkan korelasi negatif dengan intensitas serangan ulat grayak (S. litura) yang berarti semakin tinggi kerapatan trikoma daun, maka semakin rendah intensitas serangan ulat grayak (S. litura).
\end{abstract}

Kata Kunci : Kedelai, trikoma, ulat grayak

\section{Latar Belakang}

Kedelai (Glycine $\max$ L.) merupakan bahan pangan dan sebagai sumber protein nabati yang sangat penting untuk memenuhi kebutuhan pangan (Samsudin dan Dadan, 1985). Faktor yang menjadi kendala usaha tani kedelai di Indonesia adalah masalah serangan hama. Satu di antara hama kedelai adalah ulat grayak (Spodoptera litura Fabricius) yang merupakan serangga pemakan daun yang menjadi kendala dalam peningkatan produksi kedelai karena mempunyai kisaran inang yang luas atau bersifat polifag.

Kehilangan hasil akibat serangan hama tersebut dapat mencapai $80 \%$, bahkan dapat menyebabkan gagal panen (puso) jika tidak dikendalikan (Marwoto dan Bejo, 1996). Marwoto dan Bedjo (1996) mengemukakan ketahanan atau resistensi S. litura terhadap beberapa golongan insektisida telah ditemukan hampir di seluruh daerah produsen kedelai di Jawa Timur. Hal ini disebabkan oleh ketergantungan para petani terhadap penggunaan pestisida kimia yang sangat tinggi untuk menyelamatkan tanaman pokok kedelai. Melihat dampak negatif penggunaan pestisida kimia tersebut, maka dalam pengendalian hama perlu dilakukan dengan menggunakan varietas tahan hama.

Ketahanan terhadap serangga hama merupakan salah satu bagian dalam program pemuliaan yang masih perlu terus dikembangkan Boerma dan Walker (dalam Suharsono, 2001). Sifat ketahanan terhadap serangga hama dapat dilacak antara lain melalui seleksi karakteristik morfologi dan anatomi daun.

Morfologi tanaman (batang, daun dan polong) antara lain mempunyai struktur bulu yang sangat beragam dan hal tersebut diduga dapat mempengaruhi tingkat ketahanan kedelai terhadap serangan hama. Secara morfologi trikoma merupakan alat pelindung tumbuhan dari gangguan luar (Sutrian, 1992). Struktur bulu (trikoma), ukuran panjang dan kerapatan trikoma sangat berperan dalam ketahanan tanaman kedelai (Broesmana $d k k$. dalam Suharsono, 2001).

Penolakan morfologis merupakan mekanisme ketahanan fisik tanaman yang menghalangi proses makan dan peletakan telur yang normal. Menurut Singh $d k k$. (1971) dan 
Turnipseed (1977), karakteristik daun kedelai mempunyai hubungan yang erat dengan ketahanan terhadap serangga tertentu. Diduga kerapatan trikoma daun dapat menghalangi proses pengisapan atau pengambilan sari makanan oleh ulat grayak secara normal (Indiawati, 2004).

\section{Metode Penelitian}

\section{Rancangan Penelitian}

Penelitian ini merupakan penelitian eksperimen dengan RAL untuk mengetahui pengaruh galur terhadap ketahanan dari serangan ulat grayak (S. litura F.), serta penelitian deskriptif untuk mengetahui tingkat kerusakan daun oleh serangan ulat grayak, dan hubungan antara kerapatan trikoma daun dengan intensitas serangan ulat grayak pada tanaman kedelai.

\section{Waktu dan Tempat Penelitian}

Penelitian ini dilaksanakan pada bulan Juli sampai September 2010, dengan lokasi penelitian di Greenhouse Balai Penelitian Tanaman Kacang-kacangan dan Umbi-Umbian (BALITKABI) di Desa Kendalpayak Kecamatan Pakisaji Kabupaten Malang. Analisis trikoma daun dilakukan di Laboratorium Optik Jurusan Biologi Fakultas Sains dan Teknologi Universitas Islam Negeri Maulana Malik Ibrahim Malang.

\section{Subyek Penelitian}

Subyek penelitian berupa tanaman kedelai sejumlah 45 galur dan $S$. litura instar II sejumlah 450 ekor.

\section{Alat dan Bahan}

Alat yang digunakan dalam penelitian ini meliputi toples plastik berdiameter $25 \mathrm{~cm}$, polybag berukuran $20 \times 40 \times 40 \mathrm{~cm}$, cutter, timbangan digital, alat tulis, kertas label, kertas skala, kapas, tissue, kurungan kasa dan alat dokumentasi, mikroskop computer Nikon SMZ 1500 .

Bahan yang digunakan dalam penelitian ini meliputi tanah, pupuk urea, SP36, KCL, larva S. litura, dan 45 galur kedelai.

\section{Prosedur Penelitian}

\section{Perbanyakan Spodoptera litura}

Larva $S$. litura diperoleh dari tanaman kedelai di lapang. Perbanyakan dilakukan dengan memelihara $S$. litura pada toples-toples plastik (diameter $25 \mathrm{~cm}$ dan tinggi $30 \mathrm{~cm}$ ) dengan diberi pakan daun kedelai setiap hari. Setelah larva menjadi pupa, dipanen (diambil pada tanggal yang sama), diletakkan pada toples yang diberi daun kedelai (untuk menjaga kelembaban). Setelah menjadi imago diambil jantan dan betina beberapa pasang dan diberi makan larutan madu. Imago di letakkan pada tanaman kedelai (tempat bertelur) yang diberi kurungan kasa, Setelah telur menetas menjadi larva instar dua, larva tersebut siap digunakan sebagai serangga uji.

\section{Penanaman Benih}

Benih kedelai dari tiap galur ditanam dalam polybag dengan kapasitas $5 \mathrm{~kg}$ secara bersamaan yang berisikan tanah subur. Setiap polybag ditanam 3-4 biji kedelai, pada umur 10 hari dilakukan penjarangan, disisakan 2 tanaman per polybag. Pemberian pupuk dilakukan secara bersamaan pada waktu tanam dengan dosis $5 \mathrm{~g}$ urea, $10 \mathrm{~g} \mathrm{SP}-36$ dan KCL pertanaman. Galur-galur kedelai di letakkan dalam kurungan kasa dengan ukuran panjang 4 $\mathrm{m}$, lebar $4 \mathrm{~m}$ dan tinggi $2 \mathrm{~m}$. Setelah tanaman berumur 30 HST (Hari Setelah Tanam) dilepas larva $S$. litura instar II sebanyak 5 ekor larva per polybag.

\section{Pengamatan \\ Pengamatan Kerusakan Daun}

Pengamatan kerusakan daun dilakukan secara visual setelah 3 hari setelah infestasi (HSI), 6 hari setelah infestasi (HSI), 9 hari setelah infestasi (HSI), 12 hari setelah infestasi (HSI), dan 15 hari setelah infestasi (HSI) dengan menggunakan skor kerusakan daun dari skala 0-4, yaitu:

1. Skor $0=0 \%$ luas daun yang terserang / rusak

2. Skor $1=\leq 25 \%$ luas daun terserang / rusak

3. Skor $2=\geq 25-50 \%$ luas daun terserang / rusak

4. Skor $3=\geq 50-75 \%$ luas daun terserang / rusak

5. Skor $4=\geq 75-100 \%$ luas daun terserang / rusak

Intensitas serangan daun dihitung dengan rumus :

$\mathrm{I}=\frac{\sum(n \times v)}{Z \times N} \times 100 \%$

Keterangan :

$\mathrm{I}$ : Intensitas serangan (\%)

$\mathrm{n}$ : jumlah daun yang menunjukkan 
skala (v)

$\mathrm{v}$ : nilai skor daun (0-4)

$\mathrm{N}$ : jumlah daun yang diamati

$\mathrm{Z}$ : skor tertinggi (4)

Untuk melihat kategori ketahanan tanaman digunakan metode Chiang dan Talekar (dalam Nurdin, $d k k ., 1994)$ yaitu :

\begin{tabular}{|c|c|}
\hline Rumus & Kategori \\
\hline$<\mathrm{X}-2 \mathrm{SD}$ & Sangat Tahan (ST) \\
\hline $\begin{array}{l}\text { X-2SD sampai } \\
\text { dengan X-SD }\end{array}$ & Tahan $(\mathrm{T})$ \\
\hline X-SD S/d X & Agak Tahan (AT) \\
\hline $\mathrm{X} \mathrm{s} / \mathrm{d} \mathrm{X}+\mathrm{SD}$ & Rentan (R) \\
\hline$>\mathrm{X}+\mathrm{SD}$ & Sangat Rentan (SR) \\
\hline \multicolumn{2}{|l|}{ Keterangan : } \\
\hline $\mathrm{X}$ & $\begin{array}{l}\text { gka rata-rata nilai } \\
\text { gamatan }\end{array}$ \\
\hline SD & mpangan baku \\
\hline
\end{tabular}

\section{Pengamatan Kerapatan Trikoma}

Menurut Dahlin $d k k$. (dalam Rofiah, 2010).), daun yang digunakan untuk pengamatan trikoma adalah daun yang telah benar-benar terbuka yaitu daun ke -3 atau daun $\mathrm{ke}-4$ dari pucuk pada saat tanaman memasuki sadium R1. Kerapatan trikoma daun diamati dengan macrocome dengan perbesaran 15 kali. Trikoma dihitung dengan cara menghitung banyaknya trikoma pada permukaan bawah daun. Perhitungan diulang 5x tiap 1 sampel. Untuk mendapatkan trikoma, rerata yang di dapatkan dari tiga ulangan tiap 1 sampel di hitung dengan rumus :

$$
\begin{aligned}
& \mathrm{RT}=\frac{\mathrm{T} 1+\mathrm{T} 2+\mathrm{T} 3 \ldots \ldots \ldots \ldots+\mathrm{Tn}}{n} \\
& K T=\frac{R T}{L B P} \quad \mathrm{LBP}=\mathrm{P} \times 1
\end{aligned}
$$

Keterangan:

$\mathrm{T} 1=$ Trikoma bidang pandang 1

$\mathrm{T} 2=$ Trikoma bidang pandang 2

$\mathrm{T} 3=$ Trikoma bidang pandang 3

$\mathrm{Tn}=$ Ttikoma bidang pandang $\mathrm{n}$

$\mathrm{RT}=$ Rata-rata trikoma

$\mathrm{KT}=$ Kerapan trikoma

LBP $=$ Luas bidang pandang $(\mathrm{p}=6 \mathrm{~mm}, 1=4,5$ $\mathrm{mm})$.

\section{Analisis Data}

Data hasil pengamatan tentang intensitas serangan daun oleh ulat grayak pada beberapa galur kedelai dianalisis dengan analisis variansi (ANAVA) dalam RAL. Apabila analisis hasil variansi menunjukkan pengaruh nyata, maka akan dilanjutkan uji BNT dengan taraf signifikansi 95\%. Untuk mengetahui hubungan antara kerapatan trikoma daun dengan intensitas serangan ular grayak pada tanaman kedelai digunakan analisis korelasi Product Moment dari Pearson.

\section{Hasil dan Pembahasan \\ Intensitas Kerusakan Daun Beberapa Galur Kedelai (Glycine max L.) \\ Berdasarkan data perhitungan} intensitas kerusakan daun dapat diketahui bahwa tingkat kerusakan daun pada beberapa galur kedelai dapat dikategorikan sebagai berikut ST (4), T (5), AT (9), R (24) dan SR (3) (Gambar 4.1).

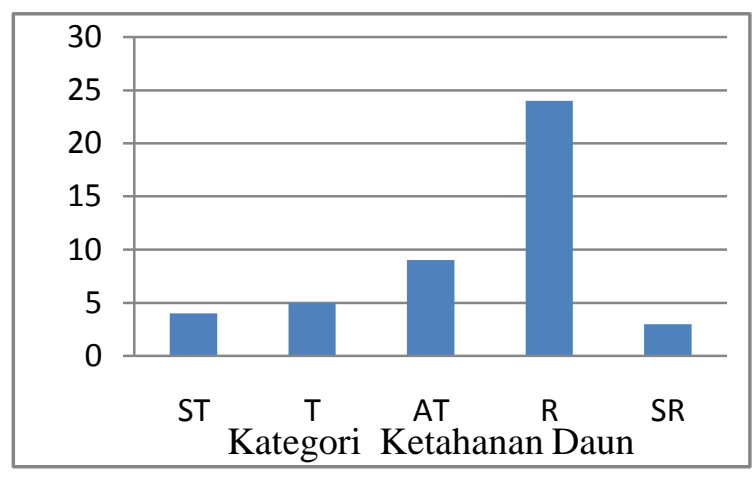

Gambar 4.1 Diagram Jumlah Galur Kedelai pada beberapa Kelompok Kategori Ketahanan.

Keterangan :

ST = Sangat Tahan $(<\mathrm{X}-2 \mathrm{SD})$

$\mathrm{T} \quad=$ Tahan $(\mathrm{X}-2 \mathrm{SD} \mathrm{s} / \mathrm{d} \mathrm{X}-\mathrm{SD})$

AT $=$ Agak Tahan $(\mathrm{X}$ s/d X)

$\mathrm{R}=\operatorname{Rentan}(\mathrm{X}$ s/d X+SD)

SR $=$ Sangat Rentan $(>X+S D)$

Hasil penelitian menunjukkan bahwa beberapa galur kedelai memiliki kriteria ketahanan yang berbeda terhadap hama Ulat grayak. Berdasarkan intensitas kerusakan daun, kategori ketahanan 45 galur kedelai (Glycine $\max$ L.) dapat dikelompokkan menjadi kategori (R) rentan sejumlah 24 galur, dan yang paling sedikit yaitu (SR) sangat rentan yaitu sebanyak 3 galur.

Ketahanan Kedelai (Glycine $\max$ L.) terhadap Serangan Ulat Grayak $(S$. litura F.) 15 HSI

Ringkasan hasil perhitungan ANAVA pengaruh perbedaan galur kedelai (Glycine max L.) terhadap intensitas serangan daun akibat serangan ulat grayak (S. litura F.) 15 HSI dapat disajikan pada tabel 4.1. 
Tabel 4.1 Ringkasan BNT 5\% Intensitas Kerusakan Daun oleh Serangan Ulat Grayak (S. litura F.) pada 15 HIS

\begin{tabular}{|c|c|c|c|c|c|}
\hline SK & $\begin{array}{l}\text { d } \\
\text { b }\end{array}$ & JK & KT & $\begin{array}{c}\mathbf{F} \\
\text { hitun }\end{array}$ & $\begin{array}{c}\mathbf{F}_{5} \\
\%\end{array}$ \\
\hline $\begin{array}{l}\text { Perlakua } \\
\mathrm{n}\end{array}$ & 44 & $\begin{array}{c}5189,0 \\
2 \\
\end{array}$ & $\begin{array}{c}117, \\
9\end{array}$ & $\begin{array}{c}\mathrm{g} \\
18 \\
7\end{array}$ & $\begin{array}{c}2,0 \\
6\end{array}$ \\
\hline Galat & 45 & 283,18 & 6,29 & & \\
\hline Total & 89 & 5472,2 & & & \\
\hline
\end{tabular}

Hasil Analisis Variansi (ANAVA) pada tabel 4.1 tersebut menunjukkan bahwa perbedaan galur kedelai berpengaruh nyata terhadap intensitas serangan daun. Hal ini dapat dilihat dari nilai $\mathrm{F}_{\text {hitung }}$ lebih besar dari $\mathrm{F}$ tabel $(18,7>2,06)$. Untuk mengetahui lebih lanjut tentang pengaruh beberapa perlakuan yang diberikan, maka dilakukan uji lanjut dengan menggunakan uji beda nyata terkecil (BNT) 5\% sebagaimana terdapat pada tabel 4.2.

Tabel 4.2. Ringkasan BNT 5\% Intensitas Kerusakan Daun oleh Serangan Ulat Grayak (S. litura F.) pada 15 HSI

\section{Galur Kedelai}

\section{Rerata Intensitas Serangan Daun (\%)}

\section{Notasi}

\begin{tabular}{|c|c|c|}
\hline IAC-100/ Burangrang & 26.13 & $\mathrm{a}$ \\
\hline Kaba/ IAC-100/ Burangrang & 26.61 & $\mathrm{ab}$ \\
\hline IAC-100/ Burangrang & 26.9 & $a b$ \\
\hline IAC-100/ Burangrang & 29.09 & ac \\
\hline IAC-100/Burangrang/Kaba & 32.03 & bd \\
\hline G 100 H/9305/IAC-100 & 34.17 & ce \\
\hline G 100 H/9305/IAC-100 & 34.17 & ce \\
\hline Anjasmoro/Argomulyo-51-1 & 34.35 & ce \\
\hline Argomulyo/Sinabung-785-1 & 34.43 & ce \\
\hline Rajabasa & 35.67 & $\mathrm{df}$ \\
\hline Anjasmoro/malabar-17-2 & 36.41 & $\mathrm{df}$ \\
\hline Anjasmoro/Malabar-18-5 & 36.6 & df \\
\hline Malabar/Anjasmoro-121-2 & 38.44 & eg \\
\hline L. Jateng/Sinabung-1028-3 & 38.65 & eg \\
\hline Anjasmoro/Argomulyo-54-1 & 38.70 & eg \\
\hline L. Jateng/Sinabung 1036-1 & 39.7 & eh \\
\hline L.Jateng/Sinabung-1028-4 & 39.75 & eh \\
\hline Kaba & 40.01 & eh \\
\hline Anjasmoro/Argomulyo-43-6 & 40.48 & fi \\
\hline Sinabung/Anjasmoro-415-4 & 41.12 & fj \\
\hline L. Jateng/Sinabung-1062-1 & 41.26 & fj \\
\hline L.Jateng/Sinabung-990-1 & 43.1 & $\mathrm{gk}$ \\
\hline L. Jateng/Sinabung-1022-1 & 43.22 & $\mathrm{gk}$ \\
\hline IAC-100/Burangrang/ Kaba & 44.34 & $\mathrm{gl}$ \\
\hline Wilis & 44.86 & $\mathrm{hl}$ \\
\hline L. Jateng/Sinabung-1000-9 & 45.26 & $\mathrm{hm}$ \\
\hline Argomulyo/Sinabung-712 & 46.36 & $\mathrm{im}$ \\
\hline Argomulyo/Anjasmoro230-2 & 46.46 & $\mathrm{jm}$ \\
\hline Argomulyo/Sinabung-852-1 & 46.63 & $\mathrm{jm}$ \\
\hline Anjasmoro/Argomulyo-32-8 & 46.83 & $\mathrm{jm}$ \\
\hline Argomulyo/Sinabung-708-1 & 46.86 & $\mathrm{jm}$ \\
\hline Sinabung/Malabar-559-3 & 47.49 & $\mathrm{~km}$ \\
\hline Sinabung/L.Jateng-599-1 & 47.67 & $\mathrm{~km}$ \\
\hline Burangrang & 47.7 & $\mathrm{~km}$ \\
\hline Anjasmoro/Argomulyo-37-3 & 48.05 & $\mathrm{kn}$ \\
\hline Anjasmoro/Argomulyo-23-1 & 48.65 & ko \\
\hline
\end{tabular}




\begin{tabular}{lcc}
\hline Argomulyo/Anjasmoro-221-1 & 48.93 & ko \\
\hline L.Jateng/Sinabung-972 & 49.05 & ko \\
\hline Anjasmoro & 49.61 & lo \\
\hline L.Jateng/Sinabung-1032-6 & 50.04 & Lo \\
\hline Sinabung/L.Jateng-653-3 & 50.98 & mo \\
\hline L. Jateng/Sinabung-1026-4 & 51.22 & mo \\
\hline Baluran & 53.68 & $\mathrm{np}$ \\
\hline Anjasmoro/Malabar-19-1 & 54.36 & op \\
\hline Anjasmoro/Argomulyo-45-1 & 57.46 & $\mathrm{p}$ \\
\hline
\end{tabular}

Tabel 4.2 menunjukkan bahwa rerata intensitas serangan daun pada pengamatan 15 HSI paling tinggi diperoleh pada galur Anjasmoro/Argomulyo-45-1yaitu sebesar 57.46 $\%$ dan rerata variabel intensitas serangan daun yang paling rendah diperoleh pada kedelai IAC100/ Burangrang, yaitu sebesar $26.13 \%$. Pada tabel 15 tersebut juga dapat diketahui bahwa intensitas kerusakan daun pada galur IAC-100/ Burangrang tidak berbeda nyata dengan galur Kaba/ IAC-100/ Burangrang; sedangkan intensitas serangan daun pada galur Anjasmoro/ Argomulyo-45-1 tidak berbeda nyata dengan galur Baluran Anjasmoro/ Malabar-19-1 dan Anjasmoro/ Argomulyo-45-1.

Berdasarkan hasil pengamatan (3 HIS15 HSI), 45 galur kedelai menunjukkan respon ketahanan yang berbeda yaitu dari tahan (toleran) menjadi rentan (peka) atau sebaliknya dari rentan (peka) menjadi (toleran). Hal tersebut terjadi karena beberapa faktor, yaitu (1) perbedaan genetik, yang dapat mengakibatkan perbedaan karakter atau ciri dari masing-masing galur, (2) preferensi makan oleh ulat grayak, jika ketersediaan makanan melimpah maka akan terjadi peningkatan populasi.

Mekanisme toleransi menurut Untung (2001), dapat terjadi karena faktor-faktor antara lain: kekuatan tanaman secara umum, pertumbuhan kembali jaringan yang rusak, ketegaran batang dan ketahanan tanaman terhadap perubahan, produksi cabang tambahan, pemanfaatan lebih efisien oleh serangga, komponensiasi lateral oleh tanaman serangga. Perbedaan tingkat ketahanan masing-masing galur kedelai di atas merupakan bawaan dari faktor genetik yang mempengaruhi perbedaan morfologi tiap galur.

\section{Hubungan antara Kerapatan Trikoma Daun dengan Intensitas Serangan Ulat Grayak pada Tanaman Kedelai}

Berdasarkan hasil analisis korelasi dapat diketahui bahwa $\left|\mathrm{r}_{\text {hitung }}\right|>\mathrm{r}_{\text {tabel }}(0,776>$ $0,291)$ dengan signifikansi $<\alpha(0,000<0,05)$ maka $\mathrm{H}_{0}$ ditolak dan $\mathrm{H}_{1}$ diterima, berarti dapat disimpulkan bahwa ada hubungan yang signifikan antara kerapatan trikoma daun dengan intensitas serangan ulat grayak pada tanaman kedelai. Nilai negatif (-) pada koefisien korelasi, menunjukkan hubungan yang berlawanan antara kerapatan trikoma daun dengan intensitas serangan ulat grayak.Semakin tinggi kerapatan trikoma daun maka semakin rendah intensitas serangan ulat grayak, begitu juga sebaliknya. 


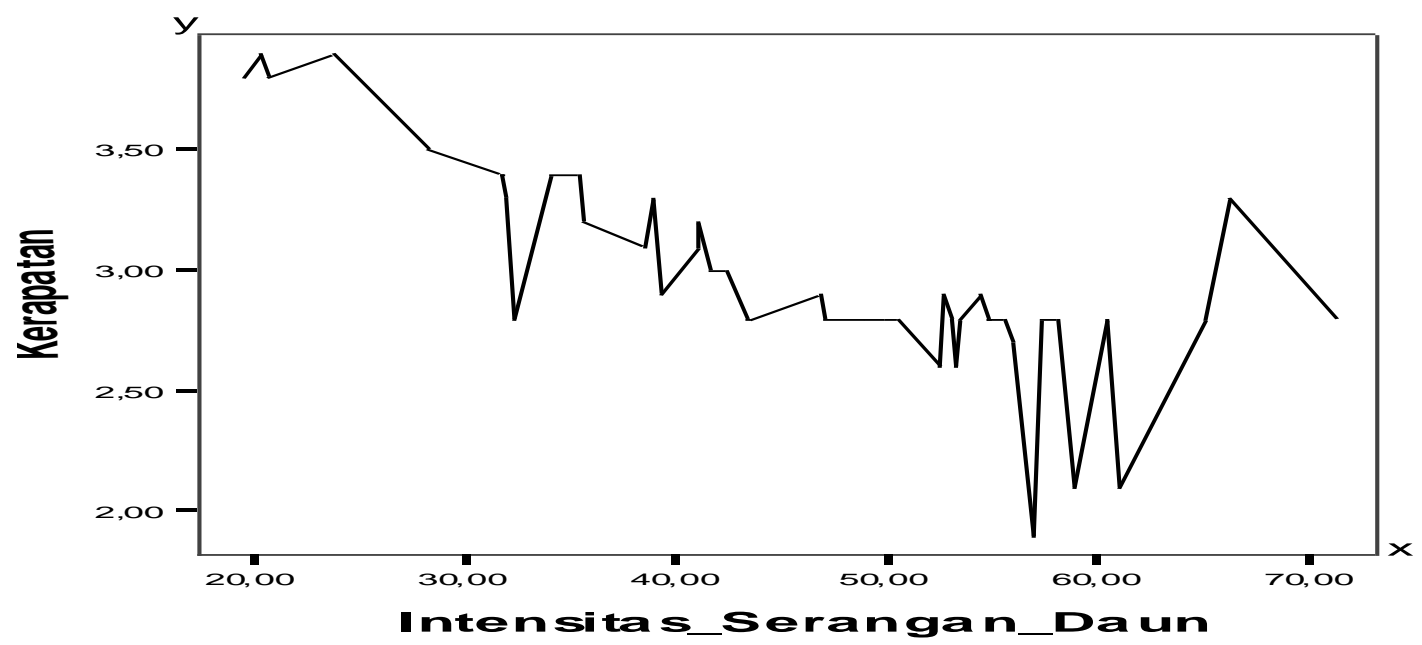

Gambar 4.2 Korelasi antara Kerapatan Trikoma Daun dengan Intensitas Serangan Ulat Grayak pada Tanaman Kedelai

Berdasarkan Gambar 4.2. dapat diketahui bahwa galur kedelai yang memiliki kerapatan trikoma 3.8-3.9 $\mathrm{mm}^{2}$ memiliki persentase $<26.94 \%$ dengan tingkat intensitas sangat tahan terhadap serangan ulat grayak, kerapatan trikoma $3.4-3.5 \mathrm{~mm}^{2}$ memiliki persentase $26.94 \%$ - $34.62 \%$ dengan tingkat intensitas tahan terhadap serangan ulat grayak, kerapatan trikoma $3.0-3.2 \mathrm{~mm}^{2}$ memiliki persentase $34.62 \%-42.30 \%$ dengan tingkat intensitas sangat tahan terhadap serangan ulat grayak, kerapatan trikoma $2.6-2.9 \mathrm{~mm}^{2}$ memiliki persentase $42.30 \%-49.98 \%$ dengan tingkat intensitas rentan terhadap serangan ulat grayak, sedangkan pada galur kedelai yang memiliki kerapatan trikoma $1.9-2.1 \mathrm{~mm}^{2}$ memiliki persentase $>49.98 \%$ dengan tingkat ketahanan sangat rentan.Hal tersebut membuktikan bahwa semakin tinggi kerapatan trikoma maka semakin tahan/toleran galur tersebut terhadap serangan ulat grayak, begitu juga sebaliknya semakin rendah kerapatan trikoma maka semakin rentan galur tersebut terhadap serangan ulat grayak.

Tingkat ketahanan kedelai terhadap ulat grayak dipengaruhi oleh faktor morfologi daun, karena adanya morfologi daun akan mempengaruhi tingkat serangan ulat grayak. Karakter morfologi daun (kerapatan trikoma, ketebalan dan kekerasan daun) dapat dijadikan sebagai bentuk mekanisme ketahanan yang efektif untuk mencegah serangan hama karena dengan adanya hambatan fisik sejak awal telah terjadi pemutusan interaksi antara inang dan hama (Adie, 1998).
Peranan trikoma sangat penting bagi setiap galur kedelai yang diuji tingkat ketahanannya terhadap hama ulat grayak. Penelitian yang dilakukan Suharsono (2001) menemukan bahwa pada tanaman kedelai yang telah dihilangkan trikomanya dengan tanaman kedelai biasa sebagai kontrol. Hal ini mengindikasikan bahwa trikoma dengan semua karakternya (rapat, panjang, dan struktur tidak beraturan) merupakan modal ketahanan morfologis terhadap hamaulat grayak.

Beberapa pakar melaporkan bahwa trikoma daun kedelai mempunyai hubungan yang erat dengan ketahanan terhadap serangga tertentu. Panjang dan kerapatan trikoma daun menghalangi proses pengisapan atau pengambilan sari makanan secara normal (Singh et al. 1971; Turnipseed, 1977). Panjang dan kerapatan trikoma pada permukaan abaksial daun kedelai juga berkorelasi dengan karakter peletakan telur lalat Agromyza (Chiang dan Norris, 1985).

\section{Kesimpulan}

1. Perbedaan galur kedelai berpengaruh terhadap ketahanan akibat serangan ulat grayak, kriteria ketahanan tanaman berdasarkan nilai intensitas kerusakan daun, dari 45 galur kedelai diketahui 4 galur tergolong kategori sangat tahan (ST), 4 galor tergolong tahan (T), 9 galur tergolong agak tahan (AT), 24 galur tergolong rentan $(\mathrm{R})$, dan 3 galur tergolong sangat rentan (SR).

2. Hasil penelitian menunjukkan hubungan negatif antara kerapatan trikoma daun 
dengan intensitas serangan ulat grayak pada tanaman kedelai, yang berarti semakin tinggi kerapatan trikoma daun maka semakin rendah intensitas serangan ulat grayak, begitu juga sebaliknya.

\section{Saran}

Perlu penelitian lebih lanjut tentang karakter morfologi daun selain kerapatan trikoma pada daun kedelai.

\section{Daftar Pustaka}

Adie, M. 1998. Peluang Pembentukan Varietas Kedelai Toleran Hama UlatGrayak, Tropik. $6: 63-68$.

Adinugroho, W. 2008. Konsep Timbulnya Penyakit. Makalah. Bogor: Mayor Silvikultur Tropika Pascasarjana IPB.

Ardiansyah. 2007. Hama Ulat Grayak (Spodoptera litura)Mengganas. Diakses tanggal 19 Februari 2010.

Arifin, M. 1991. Pertumbuhan Intristik (Spodoptera litura F) pada Tanaman Kedelai. Dalam Prosiding Lokakarya PenelitianKomoditas dan Studi Khusus Palawija. P. 453-465. M. Mahmud dkk (Ed). Balai Pangan dan Pengembangan Pertanian.

Carr, E. D and Mickey, E. 2002. Inbreeding Alters Resistence to Insect Herbivory and Host Plant Quality in Mimulus Guttatus.

www.mstate.edu/entomology/ENTPL P.html.

Chiang, H.S. and D.M. Norris, 1985. Expression and stability of soyban resistance to agromyzid beanflies. Insect Sci. App. 6: 265-270

Dasuki, U.A. 1991. Sistematika Tumbuhan Tinggi. Bandung: Penerbit ITB.

Direktorat Jendral Perkebunan. 1994. Pedoman Pengenalan Pestisida Botani. Jakarta: Direktorat Bina Perlindungan Tanaman Perkebunan. Departemen Pertanian.

Direktorat Perlindungan Hortikultura. 2007. Ulat Grayak (Spodoptera litura). http://www.deptan.go.id. Diakses tanggal 19 Februari 2010.

Direktorat Perlindungan Tanaman Pangan. 2008. Laporan Luas dan Serangan Hama dan Penyakit Tanaman Pangan di Indonesia. Jakarta : Direktorat Perlindungan Tanaman Pangan.
Hera. 2007. Ulat Grayak Makalah.http://www.deptan.go.id Diakses tanggal 19 Februari 2010.

Hidayah, N. dan Cece, S. 2010. Evaluasi Ketahanan Aksesi Kapas Terhadap Penyakit Layu Fusarium. Malang: Balai Penelitian Tanaman Tembakau dan Serat.

Indriawati, 2004. Penyaringan dan Mekanisme Ketahanan Kacang Hijau MLG-761 terhadap Hama Thrips. Jurnal Litbang Pertanian. 23 (3).

Irawan, E. 2006. Budidaya Tanaman Kedelai (Glycine $\max$ (L.) Merill). http://www.wawanshut.com. Diakses tanggal 25 Februari 2010.

Irwanto. 2006. Pengembangan Tanaman Jarak Pagar (Jatropha curcas L.) sebagai Sumber Bahan Bakar Alternatif. http://www. Irwantoshut.com. Diakses tanggal 19 Februari 2010.

Jumar. 2000. Entomologi Pertanian. Jakarta: PT. Rineka Cipta.

Kogan, M. 1982. Plant Resistence in Pest Management. Dalam R. L. Metcalf dan W. H. Luckman (eds). Introduction to Insect Pest Management. Second Edition. Newyork : John willey and Sons.

Kartono, G. 1991. Peranan Gosipol dalam Ketahanan Kapas terhadap Helicaverpa Armigerra Hubner (Lepidoptera : Noctuidae). Desertasi Doktor. Program Pasca Sarjana UGM tidak diterbitkan.

Lamina. 1989. Kedelai dan Pengembangannya. Jakarta : CV. Simplek.

Laoh, J Hannie,. 2003. Kerentanan Larva Spodoptera litura terhadap Virus Nuklear Polyhidrolis. Jurnal Natur Indonesia. 5(2); 145-151.

Marwoto dan Bejo, 1996. Resistensi Hama Ulat Daun terhadap Insektisida di Daerah Sentra Produksi Kedelai di Jawa Timur. Laporan Teknis 1996-1997. Balai Penelitian Tanaman Kacangkacangan dan Umbi-umbian, Malang.

Marwoto. 2008. Hama Penyakit dan Masalah Hara pada Tanaman Kedelai. Bogor : Departemen Pertanian.

Marwoto dan Suharsono. 2008. Strategi dan Komponen Teknologi Pengendalian Ulat Grayak (Spodoptera litura Fabricius) pada Tanaman Kedelai. Jurnal Litbang Penelitian. 27(4). 
Masnenah, 2004. Korelasi Beberapa Karakter Morfologi Dengan Ketahanan Tanaman Kedelai Terhadap Penyakit Karat. ZURIAT V 15 (1).Muhuria, LA. 2003. Strategi Perakitan GenGen Ketahanan terhadap Hama. Bandung : ITB-Pres.

Mursiani, S. 1993. Budidaya Tanaman Padi dan Palawija. Malang: Fakultas Pertanian Universitas Muhammadiyah Malang.

Najiyati, S. dan Danarti. 1999. Palawija Budidaya dan Analisis Usaha Tani. Jakarta: Penebar Swadaya.

Pracaya. 1995. Hama dan Penyakit Tumbuhan. Jakarta : Penebar Swadaya.

Rismunandar. 1973. Bertanam Kedelai. Bandung: Penerbit Tarate.

Rofiah, A. 2010. Kajian Aspek Anatomi Daun Beberapa Varietas Kedelai (Glycine max L.) pada kondisi cekaman kekeringan. Skripsi UIN Malang. Tidak diterbitkan

Rukmana, H. R. 1996. Kedelai. Yogyakarta: Kanisius.

Rusdi, T. 1990. Bercocok Tanam Kedelai. Jakarta : Karya Baru.

Samsudin, S.U. dan Dadan, S. Djakamihardja. 1985. Budidaya Kedelai. Bandung: CV. Pustaka Buana.

Sastrahidayat ., Rohdjatun, Ika. 1990. Ilmu Penyakit Tumbuhan. Surabaya: Usaha Nasional Surabaya.

Sastrodihardjo. 1979. Pengantar Entomologi Terapan. Bandung: ITB Press.

Singh. L. 1983. Modern Techniques of Raising Field Crops. New Dehli: Oxford and IBH Pulishing.

Smith, C. M. 1989. Plant Restance to Insects (Fundamental Approch). New York: John Willey and Sons.

Stren, K.R. 2003. Introductory Plant Biology. New York: McGraw-Hill.

Suharsono. 2001. Kajian Aspek Ketahanan Beberapa Genotip Kedelei terhadap Hama Penghisap Polong Riptotus linearis (Himiptera Alydidae). Disertasi Doktor Program Pasca Sarjana UGM. Tidak diterbitkan.

Suharsono,M.M., Adie Tridjaka. 1997. Pembentukan Varietas Kedelai Tahan Hama Ulat Grayak (Spodoptera litura F) (Lepidoptera: Noctuide). Habitat 10 (105).
Sukarsono. 2009. Ekologi Hewan. Malang : UMM preess.

Suprapto, H.S. 2001. Bertanam Kedelai. Jakarta : Penebar Swadaya.

Susila, S.D. dan Susanto. 2003. Kedelai, Deskripsi, Budidaya dan Sertifikasi Benih. Surabaya: Expert JICA-SSP.

Sutrian, Y. 1992. Pengantar Anatomi TumbuhTumbuhan. Jakarta: PT. Rineka Cipta.

Untung, K. 2001. Pengantar Pengelolaan Hama Terpadu. Yogyakarta : Gadjah Mada University Press. 